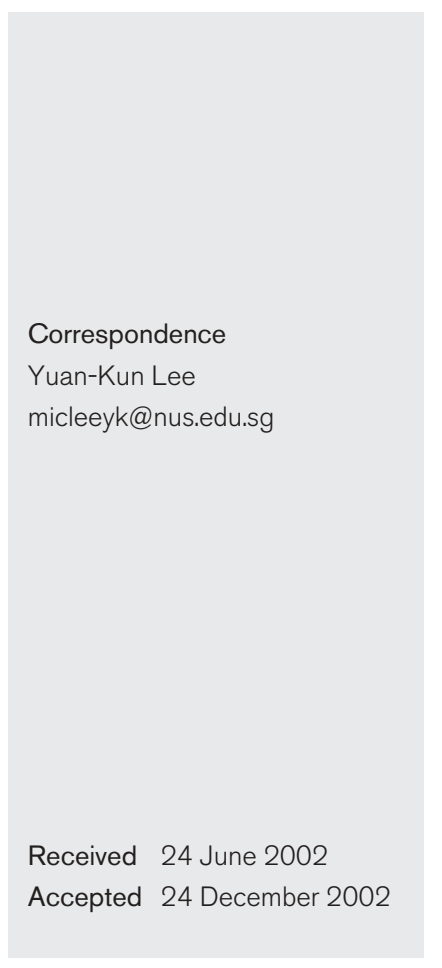

\section{Displacement of bacterial pathogens from mucus and Caco-2 cell surface by lactobacilli}

\author{
Yuan-Kun Lee, ${ }^{1}$ Kim-Yoong Puong, ${ }^{1}$ Arthur C. Ouwehand ${ }^{2}$ \\ and Seppo Salminen² \\ ${ }^{1}$ Department of Microbiology, Faculty of Medicine, National University of Singapore, 5 Science Drive 2, \\ Singapore 117597 \\ ${ }^{2}$ Department of Biochemistry and Food Chemistry, University of Turku, Fin-20014 Turku, Finland
}

\section{INTRODUCTION}

Observations have been made that Lactobacillus supplementation in food may not significantly alter the intestinal microbiota, including potential pathogens, in the gastrointestinal (GI) tract of human subjects (Millar et al., 1993; Apostolou et al., 2001). There are, however, reports that probiotic lactobacilli protect the human host (especially infants) against GI infections (Gorbach et al., 1987; Isolauri et al., 1994; Saavedra et al., 1994; Grönlund et al., 2000). These health-effects of probiotic bacteria have been attributed to non-competitive exclusion mechanisms, such as modulation of immune responses (O'Halloran et al., 1998; Pelto et al., 1998), enhancement of mucosal repair (Elliott et al., 1998; Kirjavainen et al., 1999) and non-specific proliferation enhancement of intestinal anaerobes (Apostolou et al., 2001). Probiotics have been reported to alter enzymic activities in the human intestine, which may require alteration of intestinal microflora (Goldin \& Gorbach, 1984; Ling et al., 1992). The ability of probiotic bacteria to compete with pathogens for adhesion sites on the intestinal mucosal surface is still under investigation. Ability to adhere to the surface of epithelial cells is a key pathogenic factor of intestinal pathogens (Levine, 1987; Alam et al., 1996; Weinstein et al., 1998; Scaletsky et al., 2002). Lactobacilli have been shown to possess surface adhesins similar to those on bacterial pathogens (Neeser et al., 2000). The current in vitro study of competition for adhesion to human intestinal

Abbreviations: Gl, gastrointestinal; LCS, Lactobacillus casei Shirota; LGG, Lactobacillus rhamnosus GG. mucus glycoproteins and enterocyte-like Caco-2 cell surfaces was designed to examine and characterize mechanisms of adhesion. It is hoped that these will provide a mechanistic basis for the development of selection criteria for optimal probiotics that can competitively exclude GI pathogens.

\section{METHODS}

Bacterial strains. The two probiotic lactobacilli studied are Lactobacillus casei strain Shirota (Yakult; Singapore) and Lactobacillus rhamnosus strain GG (ATCC 53103). Both bacterial strains have probiotic properties that have been demonstrated clinically (Lee et al., 1999). Lactobacilli were cultured in MRS broth (BBL) at $37^{\circ} \mathrm{C}$ in an atmosphere of $5 \%(\mathrm{v} / \mathrm{v}) \mathrm{CO}_{2}$ in air for $18-20 \mathrm{~h}$ before the study.

Escherichia coli O157, E. coli ATCC 11775, Salmonella choleraesuis subsp. choleraesuis serotype typhimurium (Salmonella typhimurium) ATCC 14028 and S. choleraesuis subsp. choleraesuis serotype enteritidis (Salmonella enteritidis) ATCC 13076 were obtained from the American Type Culture Collection (ATCC; Rockville, MD, USA). S. typhimurium E10 (NCTC 8391) was obtained from the National Collection of Type Cultures (NCTC; Colindale, UK). E. coli TG1 (Gibson, 1984) was obtained from the collection of our department, whereas S. typhimurium E12 and 'Salmonella bellurup' E23 are faecal isolates provided by the National University Hospital. These bacteria were grown in LuriaBertani broth (BBL) at $37^{\circ} \mathrm{C}$ for $18-20 \mathrm{~h}$ before use.

To label bacteria, methyl $\left(1^{\prime}, 2^{\prime}-{ }^{3} \mathrm{H}\right)$-thymidine was added to the medium at a concentration of $10 \mu \mathrm{ml}^{-1}\left(117 \mathrm{Ci} \mathrm{mmol}^{-1}\right)$. After growth, the lactobacillus strains were washed twice with sterile acetate buffer $(\mathrm{pH} \mathrm{5.0)}$ and resuspended in the same buffer. The other eight potential pathogens were washed once with acetate buffer ( $\mathrm{pH} 5.0)$ that contained $0 \cdot 1 \%(\mathrm{w} / \mathrm{v})$ sodium azide to avoid bacterial invasion. These GI bacteria were then washed once more with acetate buffer and resuspended in the same buffer. 
Intestinal cell culture. Caco-2 cell cultures were used in the adhesion assay (Fogh et al., 1977). This human colon adenocarcinoma cell-line was obtained from the ATCC. Cells were cultured in Dulbecco's modified Eagle's minimal essential medium (Gibco-BRL) that contained $25 \mathrm{mM}$ glucose, $20 \%(\mathrm{v} / \mathrm{v})$ heated inactivated fetal calf serum (Gibco-BRL) and $1 \%$ non-essential amino acids (Gibco-BRL). Cells were grown at $37{ }^{\circ} \mathrm{C}$ in an atmosphere of $5 \% \mathrm{v} / \mathrm{v} \mathrm{CO}_{2}$ in air. For the adhesion assay, monolayers of Caco-2 cells were prepared in 24-well tissue-culture dishes (Falcon type 3047; Becton Dickinson) by inoculating $1 \times 10^{5}$ viable cells per well in $1.0 \mathrm{ml}$ culture medium. Medium was replaced every 2 days.

Intestinal mucus. Human intestinal mucus glycoproteins were isolated from faeces of healthy adult volunteers by extraction and dual ethanol precipitation (Ouwehand et al., 2001). In short, faecal extracts were prepared by homogenizing faeces in PBS $(\mathrm{pH} \mathrm{7.4)}$ that contained protease inhibitors and sodium azide and centrifuging the suspension at $15000 \mathrm{~g}$. Mucus was isolated from the clear faecal extract by dual ethanol precipitation; the crude mucus was further lyophilized and stored at $4{ }^{\circ} \mathrm{C}$.

\section{Adhesion assay}

(i) On Caco-2 cells. Fifteen-days-post-confluent Caco-2 cell monolayers were washed once with $1 \mathrm{ml}$ sterile acetate buffer $(\mathrm{pH} 5 \cdot 0)$ before the adhesion assay. Bacteria at concentrations between $1 \times 10^{8}$ and $1 \times 10^{9}$ c.f.u. $\mathrm{ml}^{-1}$ were added to each well in $1.0 \mathrm{ml}$ (total volume) acetate buffer (pH 5.0) and incubated at $37^{\circ} \mathrm{C}$ in an atmosphere of $5 \%$ $(\mathrm{v} / \mathrm{v}) \mathrm{CO}_{2}$ in air with gentle rocking. After $60 \mathrm{~min}$ incubation, monolayers were washed three times with sterile acetate buffer $(\mathrm{pH}$ $5 \cdot 0)$ to remove free bacterial cells. Concentration of adhered bacterial cells was estimated from radioactivity, which was assayed by liquid scintillation (Ouwehand et al., 2001).

(ii) On immobilized mucus. Study of adhesion of micro-organisms to mucus glycoproteins was performed as described previously (Ouwehand et al., 1999). In short, $100 \mu \mathrm{l}$ human intestinal mucus

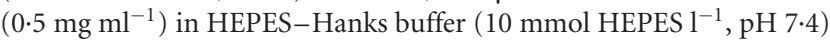
was immobilized in polystyrene microtitre plate wells (MaxiSorp; Nunc) by overnight incubation at $4{ }^{\circ} \mathrm{C}$. Wells were washed once with $200 \mu \mathrm{l}$ acetate buffer $(\mathrm{pH} 5 \cdot 0)$. Bacterial suspension $(100 \mu \mathrm{l})$ at concentrations between $1.0 \times 10^{8}$ and $5.0 \times 10^{8}$ c.f.u. $\mathrm{ml}^{-1}$ was added to the wells, followed by incubation at $37^{\circ} \mathrm{C}$ for $1.5 \mathrm{~h}$. Radioactivity was assessed by liquid scintillation.

In the study of competition exclusion for adhesion on both Caco- 2 cells and mucus, lactobacillus and the respective GI bacterium were added simultaneously or sequentially. In the latter case, free cells of the first type of bacterium were removed by washing with acetate buffer ( $\mathrm{pH} 5 \cdot 0)$ before the second type of bacterium was added.

Statistics. Differences between treatments were examined for significance by Student's $t$-test after analysis of variance. $P>0.05$ was considered to be statistically insignificant.

\section{RESULTS}

\section{Adhesion of L. rhamnosus GG (LGG) and GI bacteria on human mucin}

Competition for adhesion on the surface of mucin was observed when equal concentrations $\left(1 \times 10^{8}\right.$ cells ml $)$ of GI bacteria and LGG were incubated together (Table 1). The degree of competitive inhibition of adhesion of GI bacteria was, however, strain-dependent. E. coli O157 showed no inhibition by LGG, whereas E. coli ATCC 11775 showed the highest degree of inhibition (83.68 \%) within $1 \mathrm{~h}$ incubation.

In the exclusion study (Table 1), LGG was allowed to adhere to the mucin surface first and each of the other GI bacteria was added subsequently. The data showed that LGG adhered on the mucin surface was able to exclude all GI bacteria except $E$. coli $\mathrm{O} 157$ (no exclusion was observed), with $E$ coli ATCC 11775 showing the highest degree of inhibition ( $77 \cdot 73 \%)$ by LGG.

When GI bacteria were allowed to adhere to the mucin first and LGG was added subsequently, low degrees of displacement of the GI bacteria (0-14\%) were observed (Table 1). Adhesion of E. coli $\mathrm{O} 157$ was enhanced.

Table 1. Inhibition of adhesion of Gl bacteria by LGG on human mucin

Changes in adhesion of GI bacteria to the surface of human mucin in the absence of LGG were assigned to $0 \%$ (control).

\begin{tabular}{|lrrr|}
\hline \multirow{2}{*}{ GI bacterium } & \multicolumn{3}{c|}{ Change in adhesion, mean \pm SD (\%) } \\
\cline { 2 - 4 } & Competition & Exclusion & Displacement \\
\hline E. coli O157 & $3 \cdot 72 \pm 9 \cdot 94$ & $19 \cdot 89 \pm 45 \cdot 52$ & $53 \cdot 93 \pm 37 \cdot 02^{\star}$ \\
E. coli ATCC 11775 & $-83 \cdot 68 \pm 1 \cdot 07^{\star}$ & $-77 \cdot 73 \pm 5 \cdot 29^{\star}$ & $-7 \cdot 23 \pm 4 \cdot 74$ \\
E. coli TG-1 & $-74 \cdot 20 \pm 1 \cdot 42^{*}$ & $-69 \cdot 13 \pm 2 \cdot 20^{\star}$ & $4 \cdot 40 \pm 0 \cdot 17$ \\
S. enteritidis ATCC 13076 & $-21 \cdot 29 \pm 10 \cdot 02^{\star}$ & $-35 \cdot 74 \pm 11 \cdot 77^{\star}$ & $-13 \cdot 04 \pm 10 \cdot 35$ \\
S. typhimurium ATCC 14028 & $-61 \cdot 60 \pm 6 \cdot 95^{*}$ & $-55 \cdot 01 \pm 9 \cdot 71^{\star}$ & $-10 \cdot 19 \pm 8 \cdot 74$ \\
S. typhimurium E10 & $-70 \cdot 01 \pm 3 \cdot 44^{*}$ & $-68 \cdot 55 \pm 3 \cdot 60^{\star}$ & $-1 \cdot 08 \pm 6 \cdot 53$ \\
S. typhimurium E12 & $-25 \cdot 11 \pm 15 \cdot 26^{*}$ & $-51 \cdot 02 \pm 5 \cdot 01^{\star}$ & $-14 \cdot 25 \pm 8 \cdot 52$ \\
'S. bellurup' E23 & $-13 \cdot 52 \pm 3 \cdot 27^{\star}$ & $-14 \cdot 38 \pm 4 \cdot 92^{\star}$ & $-9 \cdot 74 \pm 5 \cdot 73$ \\
\hline
\end{tabular}

${ }^{*}$ Significantly different from control (Student's $t$-test: $P<0 \cdot 05$ ). 


\section{Adhesion of LGG and GI bacteria on Caco-2 cells}

Competition of LGG and GI bacteria, except E. coli O157, for adhesion on the surface of Caco-2 cells was observed (Table 2). E. coli TG1 showed the highest degree of inhibition ( $48.97 \%)$ by LGG.

As shown in Table 2, adhered LGG was able to exclude most GI bacteria, except 'S. bellurup' E23 and S. typhimurium E10, with $E$. coli TG1 showing the highest degree of exclusion $(37 \cdot 38 \%)$.

Free LGG was able to displace S. typhimurium E10 (45.02\%), E. coli ATCC $11775(31.05 \%)$, S. enteritidis $(8.87 \%)$ and S. typhimurium ATCC 14028 (27.49\%), but not the other GI bacteria (E. coli TG1, S. typhimurium E12, 'S. bellurup' E23 or E. coli O157) within $1 \mathrm{~h}$ incubation together (Table 2). Extension of the incubation time of LGG with adhered $S$. typhimurium ATCC 14028 for another hour ( $2 \mathrm{~h}$ in total) showed a higher degree of displacement (from 27.49 to $36 \cdot 13 \%, P<0.05$ ) (Fig. 1).

\section{Adhesion of L. casei Shirota (LCS) and GI bacteria on human mucin}

LCS was able to compete with most GI bacteria (except for 'S. bellurup' E23) for adhesion on the mucin surface (Table 3). E. coli TG1, S. typhimurium E10, E. coli O157, E. coli ATCC 11775 and S. typhimurium ATCC 14028 showed higher degrees of inhibition.

Degrees of exclusion of GI bacteria by LCS ranged between +20 and $-36 \%$, with S. typhimurium E10 and S. typhimurium ATCC 14028 showing higher degrees of exclusion by LCS (Table 3).

Degrees of displacement of adhered GI bacteria by LCS were generally low $(<23 \%)$ (Table 3$)$. No displacement was observed with E. coli TG1, S. typhimurium E10 or E. coli O157.

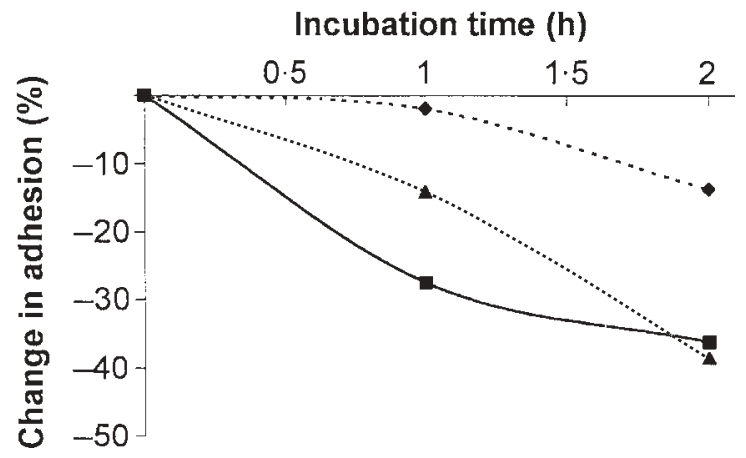

Fig. 1. Displacement study: changes in adhesion of E. coli ATCC 11775 and S. typhimurium ATCC 14028 when incubated with respective lactobacillus for different incubation time-periods. LGG+E. coli ATCC 11775; $\mathbf{n}, \mathrm{LGG}+$ S. typhimurium ATCC 14028; $\boldsymbol{\Delta}$, LCS + S. typhimurium ATCC 14028.

\section{Adhesion of LCS and GI bacteria on Caco-2 cells}

LCS was able to achieve up to $46 \%$ competitive inhibition of the GI bacteria tested (Table 4). Higher degrees of inhibition (>30\%) were observed for E. coli TG1, S. typhimurium E10, E. coli ATCC 11775 and S. typhimurium ATCC 14028.

Higher degrees of exclusion were observed for E. coli TG1, S. typhimurium E10, E. coli O157, E. coli ATCC 11775 and S. typhimurium ATCC 14028 (Table 4).

Only $\leqslant 28 \%$ displacement of GI bacteria by LCS was observed after $1 \mathrm{~h}$ incubation (Table 4). E. coli TG1 (15.78\%), E. coli O157 (no displacement), E. coli ATCC 11775 (no displacement) and S. enteritidis ATCC 13076 $(5 \cdot 22 \%)$ could not be effectively displaced by LCS within $1 \mathrm{~h}$ incubation. When the incubation time of LCS with adhered E. coli ATCC 11775 and S. typhimurium ATCC 14028 on Caco-2 cells was extended to $2 \mathrm{~h}$, more GI bacteria were

Table 2. Inhibition of adhesion of Gl bacteria by LGG on Caco-2 cells

Changes in adhesion of GI bacteria to Caco-2 cells in the absence of LGG were assigned to $0 \%$ (control).

\begin{tabular}{|lrrr|}
\hline GI bacterium & \multicolumn{3}{c|}{ Change in adhesion, mean \pm SD (\%) } \\
\cline { 2 - 4 } & Competition & Exclusion & Displacement \\
\hline E. coli O157 & $39 \cdot 99 \pm 44 \cdot 34$ & $-7 \cdot 95 \pm 3 \cdot 83$ & $-1 \cdot 17 \pm 0 \cdot 33$ \\
E. coli ATCC 11775 & $-25 \cdot 15 \pm 12 \cdot 58^{*}$ & $-27 \cdot 39 \pm 2 \cdot 08^{*}$ & $-31 \cdot 05 \pm 3 \cdot 33^{*}$ \\
E. coli TG-1 & $-48 \cdot 97 \pm 2 \cdot 06^{*}$ & $-37 \cdot 38 \pm 4 \cdot 35^{*}$ & $6 \cdot 89 \pm 0 \cdot 91$ \\
S. enteritidis ATCC 13076 & $-41 \cdot 59 \pm 3 \cdot 20^{*}$ & $-27 \cdot 53 \pm 5 \cdot 05^{*}$ & $-8 \cdot 87 \pm 3 \cdot 40$ \\
S. typhimurium ATCC 14028 & $-47 \cdot 16 \pm 2 \cdot 34^{*}$ & $-28 \cdot 20 \pm 0 \cdot 23^{*}$ & $-27 \cdot 49 \pm 3 \cdot 72^{*}$ \\
S. typhimurium E10 & $-18 \cdot 36 \pm 9 \cdot 24$ & $-4 \cdot 89 \pm 4 \cdot 04$ & $-45 \cdot 02 \pm 3 \cdot 41^{*}$ \\
S. typhimurium E12 & $-48 \cdot 15 \pm 5 \cdot 75^{*}$ & $-29 \cdot 74 \pm 4 \cdot 55^{*}$ & $-15 \cdot 35 \pm 8 \cdot 40$ \\
'S. bellurup' E23 & $-20 \cdot 99 \pm 6 \cdot 21$ & $9 \cdot 18 \pm 6 \cdot 99$ & $-4 \cdot 96 \pm 1 \cdot 32$ \\
\hline
\end{tabular}

${ }^{\star}$ Significantly different from control (Student's $t$-test: $P<0 \cdot 05$ ). 
Table 3. Inhibition of adhesion of Gl bacteria by LCS on human mucin

Changes in adhesion of GI bacteria to the surface of human mucin in the absence of LCS were assigned to $0 \%$ (control).

\begin{tabular}{|lrrr|}
\hline \multirow{2}{*}{ GI bacterium } & \multicolumn{3}{c|}{ Change in adhesion, mean \pm SD (\%) } \\
\cline { 2 - 4 } & Competition & Exclusion & Displacement \\
\hline E. coli O157 & $-56 \cdot 59 \pm 30 \cdot 77$ & $-4 \cdot 09 \pm 17 \cdot 63$ & $2 \cdot 62 \pm 6 \cdot 28$ \\
E. coli ATCC 11775 & $-57 \cdot 14 \pm 3 \cdot 54^{*}$ & $4 \cdot 20 \pm 2 \cdot 81$ & $-6 \cdot 11 \pm 1 \cdot 74$ \\
E. coli TG-1 & $-48 \cdot 62 \pm 3 \cdot 40^{*}$ & $-1 \cdot 73 \pm 2 \cdot 69$ & $-0 \cdot 55 \pm 7 \cdot 38$ \\
S. enteritidis ATCC 13076 & $-30 \cdot 70 \pm 14 \cdot 36^{*}$ & $19 \cdot 72 \pm 12 \cdot 90$ & $-13 \cdot 04 \pm 10 \cdot 35$ \\
S. typhimurium ATCC 14028 & $-42 \cdot 96 \pm 10 \cdot 16^{*}$ & $-36 \cdot 28 \pm 6 \cdot 61^{*}$ & $-10 \cdot 56 \pm 6 \cdot 07$ \\
S. typhimurium E10 & $-62 \cdot 41 \pm 6 \cdot 39^{*}$ & $-27 \cdot 35 \pm 3 \cdot 75^{*}$ & $0 \cdot 32 \pm 2 \cdot 70$ \\
S. typhimurium E12 & $-24 \cdot 23 \pm 9 \cdot 32^{*}$ & $-15 \cdot 86 \pm 8 \cdot 73^{*}$ & $-22 \cdot 62 \pm 8 \cdot 19$ \\
'S. bellurup' E23 & $8 \cdot 67 \pm 5 \cdot 89$ & $-12 \cdot 80 \pm 6 \cdot 78$ & $-18 \cdot 90 \pm 5 \cdot 44$ \\
\hline
\end{tabular}

${ }^{\star}$ Significantly different from control (Student's $t$-test: $P<0 \cdot 05$ ).

Table 4. Inhibition of adhesion of GI bacteria by LCS on Caco-2 cells

Changes in adhesion of GI bacteria to Caco-2 cells in the absence of LCS were assigned to $0 \%$ (control).

\begin{tabular}{|lccc|}
\hline \multirow{2}{*}{ GI bacterium } & \multicolumn{3}{c|}{ Change in adhesion, mean \pm SD (\%) } \\
\cline { 2 - 4 } & Competition & Exclusion & Displacement \\
\hline E. coli O157 & $-19 \cdot 92 \pm 7 \cdot 82$ & $-23 \cdot 44 \pm 7 \cdot 50^{*}$ & $-11 \cdot 13 \pm 4 \cdot 24$ \\
E. coli ATCC 11775 & $-31 \cdot 07 \pm 4 \cdot 06^{*}$ & $-28 \cdot 63 \pm 6 \cdot 25^{*}$ & $-1 \cdot 92 \pm 11 \cdot 89$ \\
E. coli TG-1 & $-45 \cdot 97 \pm 1 \cdot 62^{*}$ & $-25 \cdot 82 \pm 8 \cdot 26^{*}$ & $-15 \cdot 78 \pm 4 \cdot 91$ \\
S. enteritidis ATCC 13076 & $-4 \cdot 73 \pm 20 \cdot 19$ & $-13 \cdot 35 \pm 2 \cdot 59$ & $-5 \cdot 22 \pm 3 \cdot 08$ \\
S. typhimurium ATCC 14028 & $-34 \cdot 59 \pm 6 \cdot 55^{*}$ & $-30 \cdot 55 \pm 7 \cdot 41^{*}$ & $-14 \cdot 13 \pm 4 \cdot 52^{*}$ \\
S. typhimurium E10 & $-40 \cdot 40 \pm 5 \cdot 52^{*}$ & $-24 \cdot 82 \pm 2 \cdot 75^{*}$ & $-24 \cdot 89 \pm 3 \cdot 77^{*}$ \\
S. typhimurium E12 & $-6 \cdot 76 \pm 8 \cdot 10$ & $-18 \cdot 62 \pm 1 \cdot 71^{*}$ & $-27 \cdot 65 \pm 0 \cdot 21^{*}$ \\
'S. bellurup' E23 & $-19 \cdot 85 \pm 3 \cdot 80$ & $1 \cdot 74 \pm 0 \cdot 30$ & $-15 \cdot 79 \pm 6 \cdot 53^{*}$ \\
\hline
\end{tabular}

${ }^{\star}$ Significantly different from control (Student's $t$-test: $P<0 \cdot 05$ ).

displaced (E. coli ATCC 11775, from 1.92 to $20 \cdot 18 \%$ displacement; S. typhimurium ATCC 14028, from 14.13 to $38.49 \%$ displacement) (Fig. 1).

\section{DISCUSSION}

When incubated together, lactobacilli were able to compete with the eight GI bacteria studied for adhesion on human mucin glycoprotein and the surface of Caco-2 cells. The degree of competition was strain-dependent and was probably determined by the affinity of adhesins on respective bacterial surfaces for the stero-specific receptors that they are competing for, or their relative positions in the case of steric hindrance (Lee \& Puong, 2002). The data clearly demon- strated that each lactobacillus could only compete with a limited range of GI bacteria (including GI pathogens) for adhesion sites. For example, LGG was not able to compete with the enteropathogenic E. coli strain O157, whereas LCS failed to compete with 'S. bellurup' E23. Adhered lactobacilli were able to exclude GI bacteria to different degrees. As expected, the profile of exclusion of GI bacteria by LGG and LCS was similar to that of competition. This confirms that the mechanisms of competition inhibition and exclusion of GI bacteria by LGG and LCS are similar.

Displacement profiles for the GI bacteria by lactobacilli were, however, very different from those of competition and exclusion. Degrees of displacement were generally much lower than the degree of inhibition achieved by competition 
and exclusion. Many GI bacteria could not be displaced within $1 \mathrm{~h}$ incubation. When the incubation time was extended to $2 \mathrm{~h}$, higher degrees of displacement were observed. These results suggest that displacement of GI bacteria by LGG and LCS is a very slow process. Resident time of food material in the small intestine is about $2 \mathrm{~h}$, whereas liquid beverage stays for an even shorter period of time (Kutchai, 1988). This may not allow sufficient time for incoming LGG and LCS to displace adhered GI bacteria (including pathogens) on the intestinal surface. In the large intestine, the resident time of faecal material is much longer (up to the time it is discharged); however, most probiotic bacteria travelling along the large GI tract are probably trapped in viscous faecal material. Bacterial concentration in faecal water is much lower.

Slow displacement of adhered GI bacteria by LGG could be understood as follows. Adhesion of LGG to the mucosal surface occurs mainly via hydrophobic interactions (Lee \& Puong, 2002); thus, competition for a specific receptor that binds GI bacteria is due to steric hindrance. LGG would not be able to competitively displace an adhered GI bacterial cell unless this cell detaches from the receptor and the binding of LGG hinders the reattachment of the bacterium to the receptor. A GI bacterium with high affinity for the receptor would not detach and would reattach readily.

LCS was shown to possess multiple surface adhesins and up to four adhesins could bind to the mucosal surface at any time (Lee et al., 2000). Such an arrangement is effective for competition and exclusion interactions, as one LCS is able to out-compete up to four pathogens and an adhered LCS could exclude up to four pathogens. However, there is only a low probability that an LCS would displace four adhered pathogens simultaneously. One-to-one competition between lactobacillus and pathogen would have a better chance for the former to displace the latter.

This study has suggested that the method of delivery of probiotics to the host is an important parameter to consider in the preparation of probiotic products. A desirable carrier for probiotic bacteria should allow sufficient time and frequency for interaction between bacteria and adhesion sites on the intestinal surface. Selection of probiotics that compete directly with pathogens, as well as their ability to elicit local immunological responses and enhance recovery of damaged mucosal surfaces, would be a logical approach to the selection and development of probiotics for therapeutic treatment of GI infectious diseases.

\section{ACKNOWLEDGEMENTS}

This study was made possible by the visit of Y.-K. L. to the laboratory of S. S. under the Overseas Research Programme supported by the Office of Research, National University of Singapore.

\section{REFERENCES}

Alam, M., Miyoshi, S., Yamamoto, S., Tomochika, K. \& Shinoda, S.
(1996). Expression of virulence-related properties by, and intestinal adhesiveness of, Vibrio mimicus strains isolated from aquatic environments. Appl Environ Microbiol 62, 3871-3874.

Apostolou, E., Pelto, L., Kirjavainen, P. V., Isolauri, E., Salminen, S. J. \& Gibson, G. R. (2001). Differences in the gut bacterial flora of healthy and milk-hypersensitive adults, as measured by fluorescence in situ hybridization. FEMS Immunol Med Microbiol 30, 217-221.

Elliott, S. N., Buret, A., McKnight, W., Miller, M. J. S. \& Wallace, J. L. (1998). Bacteria rapidly colonize and modulate healing of gastric ulcers in rats. Am J Physiol 275, G425-G432.

Fogh, J., Fogh, J. M. \& Orfeo, T. (1977). One hundred and twenty-seven cultured human tumor cell lines producing tumors in nude mice. J Natl Cancer Inst 59, 221-226.

Gibson, T. J. (1984). Studies on the Epstein-Barr virus genome. $\mathrm{PhD}$ thesis, University of Cambridge, UK.

Goldin, B. R. \& Gorbach, S. L. (1984). Alterations of the intestinal microflora by diet, oral antibiotics, and Lactobacillus: decreased production of free amines from aromatic nitro compounds, azo dyes, and glucuronides. J Natl Cancer Inst 73, 689-695.

Gorbach, S. L., Chang, T. W. \& Goldin, B. (1987). Successful treatment of relapsing Clostridium difficile colitis with Lactobacillus GG. Lancet ii, 1519.

Grönlund, M.-M., Arvilommi, H., Kero, P., Lehtonen, O.-P. \& Isolauri, E. (2000). Importance of intestinal colonisation in the maturation of humoral immunity in early infancy: a prospective follow up study of healthy infants aged 0-6 months. Arch Dis Child Fetal Neonatal Ed 83, F186-F192.

Isolauri, E., Kaila, M., Mykkanen, H., Ling, W. H. \& Salminen, S. (1994). Oral bacteriotherapy for viral gastroenteritis. Dig Dis Sci 39, 2595-2600.

Kirjavainen, P. V., Apostolou, E., Salminen, S. J. \& Isolauri, E. (1999). New aspects of probiotics - a novel approach in the management of food allergy. Allergy 54, 909-915.

Kutchai, H. C. (1988). The gastrointestinal system. In Physiology, 2nd edn, pp. 649-744. Edited by R. M. Berne \& M. N. Levy. St Louis, MO: Mosby.

Lee, Y.-K. \& Puong, K.-Y. (2002). Competition for adhesion between probiotics and human gastrointestinal pathogens in the presence of carbohydrate. Br J Nutr 88 (Suppl. 1), S101-S108.

Lee, Y.-K., Nomoto, K., Salminen, S. \& Gorbach, S. L. (1999). Handbook of Probiotics. New York: Wiley.

Lee, Y.-K., Lim, C. Y., Teng, W. L., Ouwehand, A. C., Tuomola, E. M. \& Salminen, S. (2000). Quantitative approach in the study of adhesion of lactic acid bacteria to intestinal cells and their competition with enterobacteria. Appl Environ Microbiol 66, 3692-3697.

Levine, M. M. (1987). Escherichia coli that cause diarrhea: enterotoxigenic, enteropathogenic, enteroinvasive, enterohemorrhagic, and enteroadherent. J Infect Dis 155, 377-389.

Ling, W. H., Hanninen, O., Mykkanen, H., Heikura, M., Salminen, S. \& Von Wright, A. (1992). Colonization and fecal enzyme activities after oral Lactobacillus GG administration in elderly nursing home residents. Ann Nutr Metab 36, 162-166.

Millar, M. R., Bacon, C., Smith, S. L., Walker, V. \& Hall, M. A. (1993). Enteral feeding of premature infants with Lactobacillus GG. Arch Dis Child 69, 483-487.

Neeser, J. R., Granato, D., Rouvet, M., Servin, A., Teneberg, S. \& Karlsson, K. A. (2000). Lactobacillus johnsonii Lal shares carbohydratebinding specificities with several enteropathogenic bacteria. Glycobiology 10, 1193-1199.

O’Halloran, S., Feeney, M., Morrissey, D., Murphy, L., Thornton, G., 
Shanahan, F., Sullivan, G. C. \& Collins, J. K. (1998). Adhesion of potential probiotic bacteria to human epithelial cell lines. Int Dairy $J$ 8, 596.

Ouwehand, A. C., Niemi, P. \& Salminen, S. J. (1999). The normal faecal microflora does not affect the adhesion of probiotic bacteria in vitro. FEMS Microbiol Lett 177, 35-38.

Ouwehand, A. C., Tuomola, E. M., Lee, Y. K. \& Salminen, S. (2001). Microbial interactions to intestinal mucosal models. Methods Enzymol 337, 200-212.

Pelto, L., Isolauri, E., Lilius, E. M., Nuutila, J. \& Salminen, S. (1998). Probiotic bacteria down-regulate the milk-induced inflammatory response in milk-hypersensitive subjects but have an immunostimulatory effect in healthy subjects. Clin Exp Allergy 28, 1474-1479.
Saavedra, J. M., Bauman, N. A., Oung, l., Perman, J. A. \& Yolken, R. H. (1994). Feeding of Bifidobacterium bifidum and Streptococcus thermophilus to infants in hospital for prevention of diarrhoea and shedding of rotavirus. Lancet 344, 1046-1049.

Scaletsky, I. C. A., Fabbricotti, S. H., Aranda, K. R., Morais, M. B. \& Fagundes-Neto, U. (2002). Comparison of DNA hybridization and PCR assays for detection of putative pathogenic enteroadherent Escherichia coli. J Clin Microbiol 40, 1254-1258.

Weinstein, D. L., O’Neill, B. L., Hone, D. M. \& Metcalf, E. S. (1998) Differential early interactions between Salmonella enterica serovar Typhi and two other pathogenic Salmonella serovars with intestinal epithelial cells. Infect Immun 66, 2310-2318. 